\title{
A Learning Outcome-oriented Approach towards Classifying Pervasive Games for Learning using Game Design Patterns and Contextual Information
}

Citation for published version (APA):

Schmitz, B., Klemke, R., \& Specht, M. (2013). A Learning Outcome-oriented Approach towards Classifying Pervasive Games for Learning using Game Design Patterns and Contextual Information. International Journal of Mobile and Blended Learning, 5(4), 59-71. https://doi.org/10.4018/ijmbl.2013100104

DOI:

10.4018/ijmbl.2013100104

Document status and date:

Published: 01/10/2013

Document Version:

Peer reviewed version

\section{Document license:}

CC BY-NC-SA

Please check the document version of this publication:

- A submitted manuscript is the version of the article upon submission and before peer-review. There can be important differences between the submitted version and the official published version of record. People interested in the research are advised to contact the author for the final version of the publication, or visit the DOI to the publisher's website.

- The final author version and the galley proof are versions of the publication after peer review.

- The final published version features the final layout of the paper including the volume, issue and page numbers.

Link to publication

\section{General rights}

Copyright and moral rights for the publications made accessible in the public portal are retained by the authors and/or other copyright owners and it is a condition of accessing publications that users recognise and abide by the legal requirements associated with these rights.

- Users may download and print one copy of any publication from the public portal for the purpose of private study or research.

- You may not further distribute the material or use it for any profit-making activity or commercial gain

- You may freely distribute the URL identifying the publication in the public portal.

If the publication is distributed under the terms of Article $25 \mathrm{fa}$ of the Dutch Copyright Act, indicated by the "Taverne" license above, please follow below link for the End User Agreement:

https://www.ou.nl/taverne-agreement

Take down policy

If you believe that this document breaches copyright please contact us at:

pure-support@ou.nl

providing details and we will investigate your claim.

Downloaded from https://research.ou.nl/ on date: 26 Apr. 2023 


\title{
A Learning Outcome-oriented Approach towards Classifying Pervasive Games for Learning using Game Design Patterns and Contextual Information
}

\author{
Birgit Schmitz, Roland Klemke, Marcus Specht
}

\begin{abstract}
Mobile and in particular pervasive games are a strong component of future scenarios for teaching and learning. Based on results from a previous review of practical papers, this work explores the educational potential of pervasive games for learning by analysing underlying game mechanisms. In order to determine and classify cognitive and affective learning outcomes, we propose employing game design patterns for mobile games and context information. Context information, in the course of this article, is introduced as an additional characteristic feature of mobile game design patterns. With the proposed framework we aim at understanding how pervasive game content may support learning. Findings from our research indicate that context information directs the use and presentation of content within a game and thus influences learning effects of individual patterns. This work perorates with a discussion on the shortfalls and potentials, which our framework for analysis provides.
\end{abstract}

\section{Author Keywords}

Pervasive learning, mobile games, educational games, game design patterns, learning outcomes

\section{INTRODUCTION}

In the past decade, the educational system has experienced growing pressure for adaptation and change. Alteration is requisite on many fronts. One of the rather weightily ones is the younger generation's habits of using media. Today's youth is growing up with multiple forms of media, which they use on a day-to-day basis. According to recent studies by the Pew Research Centre nearly $100 \%$ of U.S. youth ages $14-17$ years possess a mobile device and already $31 \%$ of them have a smartphone. Sending text messages is "the dominant daily mode of communication" (Lenhart, 2012 , p. 2). On average, U.S. teens send 60 text messages on a typical day. Besides sending text messages, video chatting, recording and uploading video, they play. $97 \%$ of U.S. youth ages 12-17 years play video games and $48 \%$ use a cell phone to do so (Lenhart, 2009).

Alongside this development, educational practitioners and scientists have started to evaluate the educational potential of game and mobile technologies. By now, a broad range of practical studies across varied domains and applications scenarios have proved the usefulness of these technologies for the process of teaching and learning (Breuer \& Bente, 2010; Carstens \& Beck, 2010; Garrido, Miraz, Ruiz, \& Gómez-Nieto, 2011; Klopfer, Sheldon, Perry, \& Chen, 2011; Sánchez \& Olivares, 2011). Most of the existing studies still centre on technological aspects though. In order to determine factors, mechanisms and design elements that make the use of novel learning scenarios successful and transferrable, it is necessary to explore how these technologies can be used for teaching and learning (Dunleavy, Dede, \& Mitchell, 2009; Huizenga, Admiraal, Akkerman, \& Dam, 2009; Klopfer, 2008). In a first literature review of the field, the authors have provided a mapping of mobile games for learning onto the educational effects they provide by considering the specific design patterns used within the games (Schmitz, Klemke, \&Specht, 2012).

The objective of this article is to further assess and evaluate the educational potential of mobile games for learning and to better understand the specific mechanisms that have led to improved student learning and achievement. It more specifically look at pervasive and augmented reality (AR) games for learning. Methodologically, we consider evaluation reports of games that make use 
of the game design patterns Augmented Reality and Pervasive Games. We line them up against Bloom's taxonomy of educational objectives (Bloom, 1956) and analyse their context parameters in order to evaluate the learning effects these games have. The results could provide valuable insight into the working mechanisms of AR and pervasive games and may positively influence future design decisions.

\section{PERVASIVE AND AUGMENTED REALITY GAMES FOR LEARNING}

Pervasive and game-based technologies are commonly expected to gain widespread usage for educational purposes (Johnson, Levine, Smith, \& Stone, 2011; Kelly, et al., 2007; Thomas, 2006) and for the last couple of years, pervasive games have increasingly been subject to practical studies (Conolly, Stansfield, \& Hainey, 2011; Laine, Vinni, Sedano, \& Joy, 2010; Specht, Ternier, \& Greller, 2011; Tutzschke \& Zukunft, 2009).

The term pervasive games is a rather "elusive concept" (Nieuwdorp, 2007, p. 14). As an umbrella concept it includes location-based and location-aware games as well as ubiquitous games or alternate reality games (Montola, 2011). A core characteristic of pervasive games is that they enmesh the virtual worlds of computer games with the everyday world around us (Benford, Magerkurth, \& Ljungstrand, 2005). "While the structure of these games is derived from a digitally created gameworld, the games are framed by the players' real-life physical surroundings and the players' interactions with these surroundings" (Thomas, 2006, p. 41) often blurring "the boundary of game and ordinary life so much that it is hard to tell where the game starts and ordinary life begins" (Montola, 2011). To depict the range of possible genres, the Integrated Project in Pervasive Games (IPerG Project) has produced pervasive game types ranging from treasure hunts and alternate reality games to smart street sports and massively multiplayer mobile games.

The object of this study has been limited to games that are pervasive and that utilise augmented reality (AR) to enhance the real world with virtual or naturally invisible information for their gameplay (Specht, et al., 2011). It is geared to mobile AR as opposed to fixed or static AR, which "can be seen more in large screen displays in public spaces or through desktop computers and can generally only be used in that one specific place" (FitzGerald, Adams, Ferguson, Gaved, Mor, \& Thomas, 2012, p. 2). AR games are played in the real world, which they augment with computing functionality. This combination of real and virtual game elements creates "new and exciting gaming experiences for highly motivated learning" (Winkler, Ide-Schoening, \& Herczeg, 2008, p. 3441). Integrating AR technology into mobile games can give educators powerful new ways to show relationships and connections (Yuen, Yaoyuneyong, \& Johnson, 2011) and "increase learning by immersion as well as provide a richer learning experience" (Liu \& Chu, 2010, p. 633).

\section{LEARNING OUTCOMES, PATTERNS AND AR TAXONOMIES}

In a prior study, Schmitz, Klemke \& Specht, (2012) have analyzed, which learning outcomes mobile games may support. Their review includes 19 well-documented game examples published in this decade, which were explicitly designed for teaching and learning (educational games or serious games). Based on the Design Patterns for Mobile Games (Davidsson, Peitz, \& Björk, 2004), their study gives evidence that especially pervasive and augmented reality games impact motivation and knowledge gain. The review looks for validated learning effects, reported within evaluation reports of game examples, and allocates these effects to individual game design patterns. It eventually lists those effects, which can be positively assigned to a certain pattern.

Some of the game examples are explicit pervasive and/or augmented reality games. However, with regard to learning outcomes they state influence factors (patterns) other than pervasiveness or AR. The mobile game AlienContact by Dunleavy et al., (2009) for example, uses patterns such as 
Physical Navigation, Augmented Reality, Location Artifact Proximity, Team Play, Roleplaying, Imperfect Information, or Collaboration. One of the strongest motivational effects they bring forward is the fact that AR games force pupils to go outside. "The physical exploration of the school grounds (i.e., playground, sports field, neighbourhood) was highly motivating" (p. 14) and enabled students to do things (mathematics) "in a non-typical manner".

Most studies of the review refer to the patterns Augmented Realty, respectively Pervasive Games and emphasise the motivational potential these game mechanisms provide. Based on this evidence, this article will have a closer look at these patterns. Both patterns have decided definitions within the approach by Davidsson et al. (2004). Accordingly, table 1 presents an abridgement of the study results by Schmitz et al. (2012). It focuses on the patterns Augmented Realty and Pervasive Games, states the pattern descriptions, as well as the affective and cognitive learning outcomes, which the study found evidence for.

Table 1. Learning outcomes of the game patterns Pervasive Games and Augmented Reality. Adapted from Schmitz, Klemke, \& Specht, (2012)

\begin{tabular}{|c|c|c|}
\hline $\begin{array}{l}\text { Pattern/ } \\
\text { Pattern description }\end{array}$ & Affective learning outcomes & Cognitive learning outcomes \\
\hline $\begin{array}{l}\text { Augmented Reality } \\
\text { (AR) } \\
\text { Players' perception of } \\
\text { the game world is } \\
\text { created by } \\
\text { augmenting their } \\
\text { perception of the real } \\
\text { world. }\end{array}$ & $\begin{array}{l}\text { Students feel "personally embodied" in } \\
\text { the game. Their actions in the game are } \\
\text { intrinsically motivated (Rosenbaum, } \\
\text { Klopfer, \& Perry, 2006). } \\
\text { Learners are engaged and motivated to } \\
\text { learn and use foreign languages } \\
\text { (Conolly et al., 2011). } \\
\text { Learners are attentive (Wijers, Jonker, \& } \\
\text { Drijvers, 2010). } \\
\text { Students are mentally ready for learning } \\
\text { (Schwabe \& Göth, 2005). } \\
\text { Players immerse themselves in the game } \\
\text { (Carrigy, Naliuka, \& Haahr, 2010). }\end{array}$ & $\begin{array}{l}\text { Students notice and discuss geometrical } \\
\text { aspects of the world (Wijers et al., } \\
2010 \text { ). } \\
\text { They can describe and illustrate a } \\
\text { disease model (Rosenbaum et al., 2006). } \\
\text { Students reflect on the process of } \\
\text { learning (Costabile et al., 2008). }\end{array}$ \\
\hline $\begin{array}{l}\text { Pervasive Games } \\
\text { Play sessions coexists } \\
\text { with other activities, } \\
\text { either temporally or } \\
\text { spatially. }\end{array}$ & $\begin{array}{l}\text { Participants are exceptionally activated } \\
\text { (Markovic et al., 2007). } \\
\text { Learners are motivated to play the game } \\
\text { (Conolly et al., 2011). } \\
\text { Students' attitude towards learning } \\
\text { material improves (Markovic et al., } \\
\text { 2007). }\end{array}$ & $\begin{array}{l}\text { Students can recall the learned material } \\
\text { (Akkerman, Admiraal, \& Huizenga, } \\
\text { 2009). } \\
\text { Learners are able to transfer the learned } \\
\text { material (practical knowledge and } \\
\text { practical experience) (Markovic, } \\
\text { Petrovic, Kittl, \& Edegger 2007). } \\
\text { They are able to analyze and classify the } \\
\text { learned material. Students reflect on } \\
\text { their learning. They can solve problems } \\
\text { related to the object of learning. They } \\
\text { can judge and evaluate the material for a } \\
\text { given purpose - critical thinking skills. } \\
\text { (Conolly et al., 2011). }\end{array}$ \\
\hline
\end{tabular}

The pattern approach has become an acknowledged way of structuring and defining the complex issue of game design (cf. Björk \& Holopainen, 2004; Cook, 2010; Kelle, 2012; Kiili \& Ketamo, 2007; Neil, 2012). Besides this approach, there have been other attempts to classify AR learning environments. FitzGerald et al. (2012) in their approach, for example, suggest to classify AR projects for learning according to project, device or technology used, mode of interaction, method 
of sensory feedback to the user, personal or shared experience, fixed or portable experience and learning activity. From their analysis it shows that AR supports situated and constructivist learning especially in connection with elements of collaboration and student inquiry.

A connatural approach by Specht, Ternier, \& Greller (2011) classifies educational AR settings according to the educational objective and the contextual information used in the application. In their study, they describe a matrix that explicitly couples educational objectives to implementation and context. The contextual dimensions are based on an operational model of context, i.e. identity, locations, environment, relation and time. The AR patterns they identified are dynamic 3D objects, sensor-based layers, augmented books, real-world scanners collaborative tagging and annotation, and instructional AR and RWO manipulation (Specht, et al. 2011).

The aspect of contextualisation has increasingly been recognized for learning. Activities for learning, which are embedded in meaningful contexts, can be used to increase intrinsic motivation, even if they involve abstract operations (Cordova \& Lepper, 1996). Existing mobile technology and context-aware systems can enhance the real world and enrich the learning experience by filtering information selection and presentation, increasing the precision of information retrieval or making user interaction implicit (Specht, 2009a). In his article on contextualized learning services, Specht (2009b) refers to the definition of context by Zimmermann, Lorenz \& Oppermann (2007). They use five categories for describing different aspects of context: individuality, time, locations, activity and relations context. Individuality context refers to information about objects and users in the real world. Time context comprises simple points in time as well as a complete history of entities. Locations context defines location models that allow working with absolute and relative positions. Activity context reflects the entities, goals, tasks, and actions and relations context describes the social, functional, and compositional relationships an entity has established to other entities.

According to Specht (2009b), contextualized information supports learning on various levels, i.e. environmental indicators of peripheral information or direct guidance. Mobile learning games use context information to enrich their contents with contextual metadata such as locations context for example. The geometry game Mobile Math is a learning game that engages students in mathematical activities through creating virtual elements by interacting with the real world. Wijers et al. (2010) use GPS functionality to link locations to geometrical shapes and also to locate fellow players in the street. Generally, contextualization facilitates the combination of different context parameters or forms of metadata about learning objects and media. This way, it enables flexible learning support, the combination of different context parameters as well as multiple perspectives and navigations paths (Specht, 2009b).

With the introduction of contextualization in our research, we aim at more precisely analysing the mechanisms mobile learning games use and at better understanding the effects they have. Our assumption is, that the context dimension in use creates added value by influencing and varying the experience of similar patterns and thus the effect of a pattern on learning.

\section{THEORETICAL FRAMEWORK AND BASIS FOR THE ANALYSIS}

For the analysis, we kept the basic framework as suggested by Schmitz et al. (2012). They have employed the mobile game design patterns established by Davidsson et al. (2004) and the taxonomies of educational objectives established by Bloom (1956) to better understand the learning effects of mobile learning games. In the context of our research, we expanded their basic framework by further considering a contextual dimension for the patterns as suggested by Specht (2009b).

Bloom sorts learning outcomes into the three domains: (a) the affective domain, which comprises attitudes and motivational learning outcomes, (b) the cognitive domain, which deals with the recall or recognition of knowledge and the development of intellectual abilities and skills (knowledge 
learning outcomes) and (c) the psychomotor domain, which encompasses manual or physical skills or the performance of actions (manual/physical learning outcomes).

As for the cognitive learning outcomes, Bloom has defined six levels that begin with learning on the level of knowledge and advance up to comprehension, application, and the higher order skills such as analysis, synthesis and evaluation. Table 1 lists and formulates the learning outcomes in line with the verbs Bloom (1956) provided to more accurately determine the performance expectations of students for the distinct levels of the cognitive domain. For the level of Knowledge these are verbs such as define, know, label, list, match, memorize, name and order for example.

We used Bloom's taxonomy because his one-dimensional list is more concise and for a first approach more applicable than the revised, two-dimensional table of Anderson (2005), for example. Future research will elaborate on how individual patterns match the advanced matrix of Cognitive Process Dimension, which modifies Bloom's categories and Knowledge Dimension, i.e. factual, conceptual, procedural and metacognitive knowledge (Anderson, 2005).

For the analysis we collected data by revisiting practical projects, which reportedly made use of the game mechanisms Augmented Reality and Pervasive Games. In the course of these projects, possible learning outcomes were tested and evaluated.

\section{AR GAMES AND EDUCATIONAL PRACTICES}

In the following section we present the results from our analysis. Tables 2 and 3 describe the patterns Augmented Reality and Pervasive Games and state corresponding game examples with domain and source. Table 2 lists the affective learning outcomes; table 3 the cognitive learning outcomes, which we were able to extricate from the practical project papers. Furthermore, with this work, we relate the extricated learning outcomes to the usage of certain dimensions of context. As for the context dimensions we use the terms as described in Specht (2009b) as a working definition.

Table 2. Affective learning outcomes of AR and pervasive games and context dimensions

\begin{tabular}{|c|c|c|c|}
\hline $\begin{array}{l}\text { Pattern/ } \\
\text { Pattern description }\end{array}$ & Game/Domain/Source & Affective Learning Outcomes & Context Dimensions \\
\hline $\begin{array}{l}\text { Augmented } \\
\text { Reality }\end{array}$ & $\begin{array}{l}\text { Mobile Math/Geometry/ } \\
\text { Wijers et al., } 2010\end{array}$ & Learners are attentive. & $\begin{array}{l}\text { Activity, Locations } \\
\text { Time }\end{array}$ \\
\hline \multirow{3}{*}{$\begin{array}{l}\text { Players' perception } \\
\text { of the game world } \\
\text { is created by } \\
\text { augmenting their } \\
\text { perception of the } \\
\text { real world. }\end{array}$} & $\begin{array}{l}\text { Outbreak@The Institute/ } \\
\text { Virus Game/Health/ } \\
\text { Rosenbaum et al., } 2006\end{array}$ & $\begin{array}{l}\text { Learners feel "personally embodied" } \\
\text { in the game. Their actions in the } \\
\text { game are intrinsically motivated. }\end{array}$ & $\begin{array}{l}\text { Activity, Relations } \\
\text { Individuality }\end{array}$ \\
\hline & $\begin{array}{l}\text { Mobile Gamel } \\
\text { Orientation Rally } \\
\text { Schwabe \& Göth, } 2005\end{array}$ & $\begin{array}{l}\text { Students are mentally ready for } \\
\text { learning. }\end{array}$ & $\begin{array}{l}\text { Activity, Locations } \\
\text { Relations, } \\
\text { Individuality }\end{array}$ \\
\hline & $\begin{array}{l}\text { Viking Ghost } \\
\text { Hunt/History } \\
\text { Carrigy et al., } 2010\end{array}$ & $\begin{array}{l}\text { Players immerse themselves in the } \\
\text { game. }\end{array}$ & Activity, Locations \\
\hline \multirow{2}{*}{$\begin{array}{l}\text { Pervasive Games } \\
\text { Play sessions } \\
\text { coexists with other } \\
\text { activities, either } \\
\text { temporally or } \\
\text { spatially. }\end{array}$} & $\begin{array}{l}\text { ARGuing/ } \\
\text { Language Learning } \\
\text { Conolly et al., } 2011\end{array}$ & $\begin{array}{l}\text { Learners are engaged and motivated } \\
\text { to learn and use foreign languages. }\end{array}$ & $\begin{array}{l}\text { Activity, } \\
\text { Individuality }\end{array}$ \\
\hline & $\begin{array}{l}\text { Digital Economy/ } \\
\text { Markovic et al., } 2007\end{array}$ & $\begin{array}{l}\text { Learners attitude towards learning } \\
\text { material improves. } \\
\text { Learners are exceptionally } \\
\text { activated. }\end{array}$ & Activity, Locations \\
\hline
\end{tabular}


Our analysis of individual projects revealed, that both the patterns Augmented Reality and Pervasive Games use several context-parameters at the same time. The learning game MobileMath, for example, uses locations context to create geometrical shapes on a previously defined playing field (map). Students create an imaginary layer on top of the physical reality. With this setting, the instructional context provides a frame to the artifacts and real-world objects to be learned (Specht, 2009a), which is strongly related to feedback and stimulation of metacognitive processes, for example. Also, a website is used to capture and share time context and to observe the activity of a user at a certain moment. This way, the game helps connecting real world experiences with the material to be learned and at the same time provides contextual information about locations and time, which supports the learning experience. The context dimension activity comprises the entities goals, tasks and actions (Specht, 2009b) and is a core element of pervasive and AR games. The evaluation of MobileMath by Wijers et al. (2010) describes AR as essential for the increase of students' attention and motivation to get engaged with a certain topic.

The MobileGame, too, uses several context parameters such as individuality, locations or relations context. As an electronic supplement to the traditional orientation rally the MobileGame uses individuality context by virtually attaching tasks to real world objects on campus. The game element "map-navigation" provides the base for the orientation game. The delivery of contextual information about locations and activity of users in the game keeps participants interested and moved (Schwabe \& Göth, 2005). Activity context asks learners to work on various tasks at significant places. According to the report by Schwabe \& Göth, (2005) this (working on various tasks at significant places) provides the base for learners to "immerse into a mixed reality that augments both physical and social space" (p. 204).

This is substantiated by the evaluation of the pervasive learning game Digital Economy. Here too, contextual information about locations and activity positively impacts learning. The learning game Digital Economy requests students to find and analyze special everyday situations via SMS. Digital Economy too employs a website to share learner contributions and to observe the activity of a user at a certain moment. In their study, Markovic et al., (2007) report that the pervasive game produces "a higher degree of activation, more positive emotions, an improved attitude towards learning material, and also greater learning success" (p. 115).

Contextualized learning games allow for learner interaction in authentic contexts (Specht, 2009b). The Virus Game (Outbreak@The Institute) uses context parameters such as activity, individuality and relations context to engage learners with the game. It establishes social and functional relationships (relations context) by introducing different roles that interact with each other. The integration of individuality context or 'personal embodiment' allows learners' to identify with the game and the roles they played in the course of the game (Rosenbaum, Klopfer \& Perry, 2006).

Individuality context is integrated by means of a bar graph on the learner's PDA. This graph provides information about users' health. When the bar graph on the learners' PDA screen started to drop for example, they spoke and acted as though they were actually sick. Also, players who were not sick responded to sick players with fear and alarm and tried to physically move away from them (Rosenbaum et al., 2006).

As for the cognitive learning outcomes, the practical studies referred to different levels of learning outcomes. Table 3 lists the cognitive learning outcomes aligned to the list of verbs provided by Bloom, thus suggesting a relation of the effects to the different levels. Many of the learning outcomes are lower order. Still, AR and pervasive games can lift students into the higher order outcomes such as evaluate and create (Conolly et al., 2011), which are more complex and abstract.

Context information about locations is a natural element of AR and pervasive games. Orientation rallies or games that support the exploration of sites, for example, implement context information to 
display map overlays or to filter information objects. The role-playing game Frequency 1550, for example, supports the city history curriculum at the Montessori school in Amsterdam, blends Internet and mobile phone game-play with location-based interactions. Context-parameters are used concurrently. Locations context is used to explore, map and gain knowledge of the individual areas of medieval Amsterdam and their associated themes. Students create an imaginary layer on top of the physical reality. Also, a website is used to capture and share time context and also to observe the activity of a user at a certain moment. Two maps are provided, one about medieval Amsterdam and one about present Amsterdam, that have colored dots indicating the routes of team members.

Table 3. Cognitive learning outcomes of $A R$ and pervasive games and context dimensions

\begin{tabular}{|c|c|c|c|}
\hline $\begin{array}{l}\text { Pattern/ } \\
\text { Pattern description }\end{array}$ & Game/Domain/Source & Cognitive Learning Outcomes & $\begin{array}{l}\text { Context } \\
\text { Dimensions }\end{array}$ \\
\hline \multirow{3}{*}{$\begin{array}{l}\text { Augmented } \\
\text { Reality } \\
\text { Players' perception } \\
\text { of the game world } \\
\text { is created by } \\
\text { augmenting their } \\
\text { perception of the } \\
\text { real world }\end{array}$} & $\begin{array}{l}\text { Time Warp/History } \\
\text { Blum et al., } 2012 \\
\text { McCall et al., } 2011\end{array}$ & $\begin{array}{l}\text { Learners understand spatial attributes } \\
\text { (size and location) of a specific } \\
\text { object }\end{array}$ & $\begin{array}{l}\text { Activity } \\
\text { Locations }\end{array}$ \\
\hline & $\begin{array}{l}\text { Virus Game } \\
\text { Outbreak@The } \\
\text { Institute/ } \\
\text { Health } \\
\text { Rosenbaum et al., } 2006\end{array}$ & $\begin{array}{l}\text { Learners can describe and illustrate a } \\
\text { disease model }\end{array}$ & $\begin{array}{l}\text { Activity, } \\
\text { Relations } \\
\text { Individuality }\end{array}$ \\
\hline & $\begin{array}{l}\text { Explore!/History } \\
\text { Costabile et al., } 2008\end{array}$ & $\begin{array}{l}\text { Students reflect on the process of } \\
\text { learning. }\end{array}$ & $\begin{array}{l}\text { Activity, } \\
\text { Locations, Time }\end{array}$ \\
\hline \multirow[t]{3}{*}{$\begin{array}{l}\text { Pervasive Games } \\
\text { Play sessions } \\
\text { coexists with other } \\
\text { activities, either } \\
\text { temporally or } \\
\text { spatially. }\end{array}$} & $\begin{array}{l}\text { ARGuing/Language } \\
\text { Learning } \\
\text { Conolly, et al., } 2011\end{array}$ & $\begin{array}{l}\text { Learners are able to analyze and } \\
\text { classify the learned material. } \\
\text { Students can solve problems related } \\
\text { to the object of learning. They can } \\
\text { create new problems related to the } \\
\text { object of learning They can judge } \\
\text { and evaluate the material for a given } \\
\text { purpose - critical thinking skills. }\end{array}$ & $\begin{array}{l}\text { Activity } \\
\text { Individuality }\end{array}$ \\
\hline & $\begin{array}{l}\text { Frequency } 1550 \\
\text { Akkerman et al., } 2009 \\
\text { Admiraal et al. (2011) }\end{array}$ & $\begin{array}{l}\text { Students can recall the learned } \\
\text { material. }\end{array}$ & $\begin{array}{l}\text { Activity, Time } \\
\text { Relations, } \\
\text { Locations, }\end{array}$ \\
\hline & $\begin{array}{l}\text { Digital Economy/ } \\
\text { Markovic et al., } 2007\end{array}$ & $\begin{array}{l}\text { Learners are able to transfer the } \\
\text { learned material (practical } \\
\text { knowledge and practical experience). }\end{array}$ & $\begin{array}{l}\text { Activity } \\
\text { Locations }\end{array}$ \\
\hline
\end{tabular}

Blum et al. (2012) evaluated TimeWarp, a game that uses UMPCs to provide an AR view of the environment. TimeWarp uses context parameters such as locations, activity and time context to explore the medieval history of Cologne. Context information on time is a core component of the game play ranging from roman time to medieval time and the future. Time context in the course of TimeWarp frames the learning and is coupled with activity context. Each time period holds a challenge for the learner. TimeWarp also provides context information on locations. A map shows the players' current position as soon as they get within range of interesting places marked on the map and virtual objects are overlaid on the live camera image of the UMPC. From the game evaluation the authors infer that this provides perfect opportunity to "increase the understanding of size and location of a specific object. [...] Including objects of a size that forces players to walk around them to fully take them in is one possible option". (p. 718). 


\section{DISCUSSION}

In the course of our analysis, we identified inter-relations between game design patterns, context information and learning outcomes. From the game examples it showed that context information impacts and varies the use of a pattern (different pattern instances) and that these variations or contextualized patterns refer to different aspects within the process of learning.

Findings provide evidence that the appropriate use of context information has potential to increase the motivational appeal of educational game contents, for example. Within the process of learning this refers to the initial consideration whether context information has potential to make the instructional material more intrinsically interesting (Cordova \& Lepper, 1996). The pervasive and AR game patterns enabled attention, activation, motivation, attitude and identification. They made use of several context parameters such as activity, relations or individuality context. The study by Rosenbaum et al. (2006), for example, referred to motivation in the sense of intrinsic motivation. Their evaluation linked motivation to the aspect of identification or 'personal embodiment' within the game, which originated from learners' identification with the game and the roles they played in the course of the game. Furthermore, there was mention of attention and activation, which was used in the sense of attention and activation as a base for engagement (Markovic et al., 2007, Wijers et al., 2010). The mention of motivation and attitude referred to the aspect of learners' motivation to deal with the instructional material (Markovic et al., 2007) respective the game (Conolly et al., 2011).

Educational psychologists put forth the argument that the decline in intrinsic motivation is mostly due to the de-contextualization of instruction. The converse argument, i.e. that the appropriate use of contextualization is one of the many techniques with which it is possible to increase intrinsic motivation (Cordova \& Lepper, 1996), further strengthens our findings. AR and pervasive games naturally use context information, e.g. locations or relations context, within their game play.

Also, the practical papers provided information on the potential to increase knowledge gain. Relations context, for example, is a strong component within games for it may trigger empathetic arousal and enables perspective taking, which again abets active learning. The wide range of technology implemented in pervasive and AR games ideally benefits this component. The consideration of contextual information on the learners' (game) identity together with information about relations is a frequently used element in AR games (Dunleavy et al., 2009, Facer et al., 2004, Fotouhi-Ghazvini, et al., 2009).

Matching patterns and context information indicated that context parameters, which implied educational benefits, were used to frame the learning process, e.g. context information on time (Blum et al., 2012), context information on relations (Rosenbaum et al., 2005). Framing processes relate the content that is displayed to other content or meta-information thus linking information (Specht, 2009a). Locations context usually functions as synchronizing instance, i.e. at certain instances or places within the game-play the user and digital artefacts are synchronized thus enabling the delivery of specific information at specific places or periods in time, e.g. the game-play of TimeWarp and Digital Economy. Context information about locations as seen from an educational point of view is "strongly related to the inquiry-based approaches to learning support" (Specht et al., 2011, p.122).

However, the games we presented were not explicitly designed on the base of the design patterns for mobile games. Thus, terms are used interchangeably, which makes a definite allocation and attribution of the effects we extricated difficult.

In order to verify findings from the present study and to generalize the assumed pattern context inter-relations, future research needs to scrutinize the relationship of context information and other game design patterns or groups of related patterns in-depth. Looking at individual patterns is difficult though as games rarely employ isolated patterns but a set of diverse patterns. The Virus 
Game uses patterns such as Augmented Reality, Collaborative Actions, Common Experiences, Imperfect Information, Physical Navigation, Player-Location Proximity, Score, Team Play and Roleplaying. The positive learning outcomes stated in the evaluation report can be correlated with the patterns Augmented Reality, Collaborative Actions and Roleplaying, for example. This is in line with related research, which argues that game design patterns should not exist alone and that choosing one game design pattern almost automatically requires the presence of other game design patterns (Kelle, 2012). Huizenga et al. (2009), for example, state that the provision of the pattern Competition positively influenced students' learning. The game however additionally provided for the patterns Team Play, Score and Cooperation, which had an impact on the competition between the groups too. Thus, we argue that further research is needed that investigates existing dependencies between patterns and learning outcomes in order to verify the effectiveness of mobile learning games and to corroborate their educational value.

Pervasive and augmented games for learning address a broad variety of topics, target groups and educational domains. The games we included comprise domains such as history learning (Blum et al., 2012), geometry (Wijers et al., 2010), language learning (Conolly et al., 2011; Dunleavy et al., 2009) or medicine/health (Rosenbaum et al., 2006). In the course of our review we did not evaluate in-depth how the domain interacts with the design patterns and possible learning outcomes. This will be part of a more extensive analysis. Also, we did not consider possible technical or pedagogical challenges that often go together with the use of AR for learning (FitzGerald et al., 2012).

With this paper, we do not intend to provide a strict one-to-one mapping of patterns to certain learning outcomes. Just as in traditional education, there is no "magic bullet" (Hattie, 2008) in the sense of one for all. Every objective goes together with an individual set of instructional approaches and techniques (Anderson, 2005). Also, educational interventions address individual groups of learners and thus learning methods need to be proved effective over and over again and if necessary, they have to be adjusted. Therefore, this research intends to offer a "display case'- like choice of options, i.e. linking patterns with possible learning outcomes and give examples for their implementation.

Last but not least, this article is based upon practical research frequently at the stage of prototypes. It thus faces the same perils than the underlying practical papers with regard to validity and reliability. Montola (2011) in his review on mixed-reality game prototypes analogically refers to problems frequently related to such settings, e.g. the fact that the introduction of a novel approach always leads to bias in an evaluation. Also, research with prototypes often uses small test audiences (even below $\mathrm{n}=10$ ), which makes generalization difficult.

\section{CONCLUSION}

This paper's contribution to research in the field is threefold. First, we presented an overview of current research in the field of $\mathrm{AR}$ and pervasive games for learning and outlined existing approaches for classifying them. Second, we introduced a framework for further analysis and appreciation of how mobile game-based learning content may support learning. The proposed framework extends an already existing framework by linking learning outcomes, patterns and context information. Five dimensions of context information are introduced that further specify the realization of the patterns Augmented Reality and Pervasive Games. Third, we presented results from our analysis, which showed that the link between context information and learning outcome helps to better understand the effects of individual patterns and their linkage to the process of learning. Context information adds further qualitative information to the pattern and as a result, varies the role of a pattern for mobile game design. The learning outcomes we identified were influenced by context parameters such as locations, activity and relations. 
Generally, mapping learning outcomes, patterns and context information may lead to a better understanding of AR and pervasive games for learning and feasible results, which are suitable as a base for design guidelines that define (a) patterns, which support the achievement of a desired learning outcome and (b) ways of applying them. However, in order to better understand how mobile games support teaching and learning, further quantitative and qualitative research is needed to validate these results in regard to other design patterns for mobile games currently in existence.

\section{REFERENCES}

Admiraal, W. Huizenga, J. Akkerman, S. \& Dam, G. (2011). The concept of flow in collaborative game-based learning. Computers in Human Behavior, 27(3), 1185-1194.

Akkerman, S., Admiraal, W., \& Huizenga, J., (2009) Storification in history education: a mobile game in and about medieval Amsterdam, Computers \& Education, 52(2), 449-459.

Anderson, L. W. (2005). Objectives, evaluation, and the improvement of education. Studies in Educational Evaluation, 31(2-3),102-113.

Benford, S., Magerkurth, C. \& Ljungstrand, P. (2005). Bridging the Physical, Digital in Pervasive Gaming. Communications of the ACM, 48(3), 54-57.

Bloom, B. S. (1956). Taxonomy of educational objectives, Handbook 1: Cognitive domain. New York: David McKay.

Blum, L., Wetzel, R., McCall, R., Oppermann, L., \& Broll, W. (2012). The final TimeWarp: using form and content to support player experience and presence when designing location-aware mobile augmented reality games. Proceedings of the Designing Interactive Systems Conference, (pp. 711-720). New: York ACM Press.

Breuer, J., \& Bente, G. (2010). Why so serious? On the Relation of Serious Games and Learning. Eludamos. Journal for Computer Game Culture, 4(1), 7-24.

Björk, S., \& Holopainen, J. (2004). Patterns in Game Design. Boston, MA: Charles River Media.

Carrigy, T., Naliuka, K., Paterson, N., \& Haahr, M. (2010). Design and Evaluation of Player Experience of a Location-Based Mobile Game. Proceedings of NordiCHI, (pp. 92-101). Reykjavik, Iceland: ACM Press.

Carstens, A., \& Beck, J. (2010). Get Ready for the Gamer Generation. TechTrends, 49(3), 22-25.

Conolly, T.M., Stansfield, M., \& Hainey, T. (2011). An alternate reality game for language learning: ARGuing for multilingual motivation. Computers \& Education, 57(1), 1389-1415.

Cook, J. (2010). Mobile Phones as Mediating Tools within Augmented Contexts for Development. International Journal of Mobile and Blended Learning, 2(3), 1-12.

Cordova, D. I., \& Lepper, M. R. (1996). Intrinsic motivation and the process of learning: Beneficial effects of contextualization, personalization, and choice. Journal of Educational Psychology, 88(4), 715-730.

Costabile, M. F., De Angeli, A., Lanzilotti, R., Ardito, C., Buono, P., \& Pederson, T. (2008). Explore! possibilities and challenges of mobile learning. Proceeding of the twenty-sixth annual SIGCHI conference on Human factors in computing systems, (pp. 145-154). ACM Press.

Davidsson, O., Peitz, J., \& Björk, S. (2004). Game design patterns for mobile games. Project report to Nokia Research Center, Finland. Retrieved August 15, 2010 from http://procyon.lunarpages.com/ gamed3/docs/Game_Design_Patterns_for_Mobile_Games.pdf

Dunleavy, M., Dede, C., \& Mitchell, R. (2009). Affordances and limitations of immersive participatory augmented reality simulations for teaching and learning. Journal of Science Education and Technology, 18(1), 7-22. 
Facer, K., Joiner, R., Stanton, D., Reid, J., Hull, R., \& Kirk, D. (2004). Savannah: mobile gaming and learning? Journal of Computer Assisted Learning, 20(6), 399-409.

FitzGerald, E., Adams, A., Ferguson, R., Gaved, M., Mor, Y. \& Thomas, R. (2012). Augmented reality and mobile learning: the state of the art. 11th World Conference on Mobile and Contextual Learning (mLearn 2012), 16-18 October 2012, Helsinki, Finland.

Fotouhi-Ghazvini, F., Earnshaw, R.A., Robison, D., \& Excell, P. S. (2009). Designing Augmented Reality Games for Mobile Learning using an Instructional-Motivational Paradigm. Proceedings of International Conference on CyberWorlds, IEEE, DOI 10.1109/CW.2009.27.

Garrido, P. C., Miraz, G. M., Ruiz, I. L., \& Gómez-Nieto, M. Á. (2011). Use of NFC-based Pervasive Games for Encouraging Learning and Student Motivation. Proceedings of 3rd International Workshop on Near Field Communication. IEE Computer Society. DOI: 10.1109/NFC.2011.13.

Hattie, A. C. (2008). Visible Learning. A synthesis of over 800 meta-analyses relating to achievement. London \& New York: Routledge.

Huizenga, J., Admiraal, W., Akkerman, S., \& Ten Dam, G. (2009). Mobile game-based learning in secondary education: engagement, motivation and learning in a mobile city game. Journal of Computer Assisted Learning, DOI: 10.1111/j.1365-2729.2009.00316.x.

IPerG Project. Integrated Project on Pervasive Gaming. Project website last visited on 10.12.2012: http://www.pervasive-gaming.org/iperg_games0.php

Johnson, L., Levine, A., Smith, R., \& Stone, S. (2011). The 2011 Horizon Report. Austin, Texas: The New Media Consortium.

Kelle, S. (2012). Game Design Patterns for Learning. Doctoral dissertation. Aachen: Shaker Verlag.

Kelly, H., Howell, K., Glinert, E., Holding, L., Swain, C., Burrowbridge, A. \& Roper, M. (2007). How to Build Serious Games? Communications of the ACM, 50(7), ACM.

Kiili, K., \& Ketamo, H. (2007). Exploring the Learning Mechanism in Educational Games. Journal of Computing and Information Technology - CIT 15(4), 319-324.

Klopfer, E. (2008). Augmented Learning. Research and Design of Mobile Educational Games. Cambridge, Mass.: The MIT Press.

Klopfer, E., Sheldon, J., Perry, J., \& Chen, V. H.-H. (2011), Ubiquitous games for learning (UbiqGames): Weatherlings, a worked example. Journal of Computer Assisted Learning. DOI: 10.1111/j.1365-2729.2011.00456.x.

Laine, T. H., Vinni, M., Sedano, C. I., \& Joy, M. (2010). On designing a pervasive mobile learning platform. ALT-J, Research in Learning Technology, 18(1), 3-17.

Lenhart A. (2009). Teens, Mobile \& Games. An overview of Pew Internet Data. Pew Internet \& American Life Project. Retrieved December 2, 2012 from http://www.pewinternet.org/ Presentations/2009/28--Teens-Mobile-Phones-and-Video-Gaming.aspx

Lenhart A. (2012). Teens, Smartphones \& Texting. Pew Internet \& American Life Project. Retrieved December 2, 2012 from http://www.pewinternet.org/Reports/2012/Teens-andsmartphones.aspx

Liu, T.-Y., \& Chu, Y.-L. (2010). Using ubiquitous games in an English listening and speaking course: Impact on learning outcomes and motivation. Computers \& Education, 55(2), 630-643.

Markovic, F., Petrovic, O., Kittl, C., \& Edegger, B., (2007) 'Pervasive learning games: a comparative study', New Review of Hypermedia and Multimedia, 13(2), 93-116. 
McCall, R., Wetzel, R., Löschner, J., \& Braun, A.-K. (2011). Using presence to evaluate an augmented reality location aware game. Pers Ubiquit Comput, 15(25-35). DOI: 10.1007/s00779010-0306-8.

Montola, M. (2011). A ludological view on the pervasive mixed-reality game research paradigm. Personal and Ubiquitous Computing, 15/1. DOI: 10.1007/s00779-010-0307-7

Neil, T. (2012). Mobile Design Pattern Gallery. O’Reilly Media.

Nieuwdorp, E. (2007). The Pervasive Discourse: An Analysis. Computers in Entertainment. DOI: $10.1145 / 1279540.1279553$.

Rosenbaum, E., Klopfer, E., \& Perry, J. (2006). On Location Learning: Authentic Applied Science with Networked Augmented Realities. Journal of Science Education and Technology, 16(1), 3145.

Sánchez, J., \& Olivares, R. (2011). Problem solving and collaboration using mobile serious games. Computers \& Education, 57(3), 1943-1952.

Schmitz, B, Klemke, R., \& Specht, M. (2012). Effects of mobile gaming patterns on learning outcomes: A literature review. International Journal of Technology Enhanced Learning, 4(5-6), 345-358.

Schwabe, G., \& Göth, C. (2005). Mobile learning with a mobile game: design and motivational effects. Journal of Computer Assisted Learning, 21(3), 204-216.

Specht, M. (2009a). Learning in a technology-enhanced world: Context in ubiquitous learning support. Inaugural Address. Heerlen, The Netherlands: Open University of the Netherlands.

Specht, M. (2009b). Towards Contextualized Learning Services. In R. Koper (Ed.), Learning Network Services for Professional Development (pp. 241-253). Berlin Heidelberg: Springer.

Specht, M., Ternier, S., \& Greller, W. (2011). Dimensions of Mobile Augmented Reality for Learning: A First Inventory. Journal of the Research for Educational Technology (RCET), 7(1), 117-127.

Thomas, S. (2006). Pervasive learning games: Explorations of hybrid educational gamescapes. Simulation \& Gaming, 37(1), 41-55.

Tutzschke, J. P.,.\& Zukunft, O. (2009). FRAP: A Framework for Pervasive Games. Proceedings of 1st ACM SIGCHI Symposium on Engineering Interactive Computing Systems, 133-142. New York: ACM. DOI: 10.1145/1570433.1570459.

Wijers, M., Jonker, V., \& Drijvers, P. (2010). MobileMath: exploring mathematics outside the classroom. ZDM, 42(7), 789-799.

Winkler, T., Ide-Schoening, M., \& Herczeg, M. (2008). Mobile Co-operative Game-based Learning with Moles: Time Travelers in Medieval Ages. In K. Mc Ferrin, R. Weber, R. Carlsen, \& D. A. Willis (Eds.), Proceedings of SITE, 3441-3449. Chesapeak, VA: AACE.

Yuen, S., Yaoyuneyong, G., \& Johnson, E. (2011). Augmented reality: An overview and five directions for AR in education. Journal of Educational Technology Development and Exchange, $4(1), 119-140$.

Zimmermann, A., Lorenz, A., \& Oppermann, R. (2007). An Operational Definition of Context. Proceedings of the 7th International and Interdisciplinary Conference on Modeling and Using Context (CONTEXT-07). 